Article

\title{
The Effect of Barley Cover Crop Residue and Herbicide Management on the Foliar Arthropod Community in No-Till Soybeans
}

\author{
Armando Rosario-Lebron, Alan W. Leslie* (D), Guihua Chen and Cerruti R. R. Hooks \\ Department of Entomology, University of Maryland, College Park, MD 20742, USA; \\ rosarioumdta@gmail.com (A.R.-L.); gchen06@gmail.com (G.C.); crrhooks@umd.edu (C.R.R.H.) \\ * Correspondence: aleslie@umd.edu; Tel.: +1-301-405-7877
}

Received: 10 May 2018; Accepted: 30 May 2018; Published: 1 June 2018

\begin{abstract}
Cover cropping has long been used as a method of reducing soil erosion, increasing soil quality, and suppressing weeds. However, the effects of cover crops in local farming systems are varied and can be affected by timing and method of termination. Field experiments were conducted at two sites in Maryland, USA during the 2013 and 2014 growing seasons to examine how varying the date and method of terminating a barley (Hordeum vulgare) cover crop affects the arthropod communities in succeeding no-till soybean (Glycine max). Experimental treatments included early-kill with pre- and post-emergent herbicides (EK), late-kill with pre- and post-emergent herbicides (LK), late-kill with a flail mower and pre-emergent herbicide (FM), and a fallow /bare-ground check with pre- and post-emergent herbicides (BG). Terminating barley late, just prior to soybean planting, resulted in significantly greater biomass accumulation in LK and FM than EK. However, method and timing of termination had no effect on the community of pest and beneficial arthropods in the soybean canopy. Results from this experiment suggest that terminating the cover crop early or late (just prior to crop planting) or using a mower or post-emergent herbicide will result in a similar community of arthropods within the soybean canopy.
\end{abstract}

Keywords: predators; insect pests; spider; habitat complexity; cultural control

\section{Introduction}

Cover cropping has long been used to reduce soil erosion in agricultural fields, and to retain post-harvest residual nutrients or add nutrients by fixing atmospheric nitrogen [1]. Field crop producers typically plant cereal or cereal-legume cover crop mixtures to provide ground coverage during periods when cash crops are not in season [2]. Cover cropping practices are diverse and vary according to land managers' goals. For example, cover crops can be grown with cash crops as living mulches that exist throughout the cash crop growth cycle [3] and as naturally senescing companion plants (dying mulches) that are timed to senesce at an ideal period during the cash crop cycle [4]. However, most cover crops are planted in the fall and terminated chemically prior to cash crop planting in the spring. This is done primarily to reduce competition for resources with the main crop [5]. Cover crop termination results in plant residue that remains on the soil surface. These surface residues vary in dry biomass that persists through the growing season partially based on total cover crop biomass that has accumulated just prior to termination [6].

Cover cropping has emerged as a viable weed management tool in conservation agricultural systems. When cover crops are terminated in reduced- and no-till cropping systems, resulting residues help prevent weed establishment $[7,8]$. Thus, it has been well established that cover crop residue can influence weed populations $[9,10]$. Notwithstanding, variation in cover crop biomass may impact 
weed levels differently. Greater production of cover crop biomass can enhance weed suppression through greater residue coverage and length of residue persistence [11]. Though several studies have investigated the impact of cover crop residue on weed establishment in succeeding crops, limited research has been directed at examining how this residue impacts arthropods in the subsequent cash crop. The additional vegetative biomass from cover crop residue could affect arthropod populations by altering the structural complexity of the habitat.

The effects of increased habitat complexity through greater vegetation diversity on arthropod populations within agricultural systems have been well studied [12-15]. Lawton and Strong [12] provide a definition of habitat complexity where simple habitats are those with lower biomass and diversity of plant resources and architecture. Plant architecture may be described as the height, heterogeneity, and structural complexity of plant or plant material. As such, non-living ground coverage or cover crop residue can be a vital contributor to agricultural habitat complexity. When a cover crop is terminated, the resulting residue is projected to increase habitat complexity through soil coverage [16-18]. Increased habitat complexity in agro-ecosystems is predicted to increase the diversity of arthropods within the habitat and the ability of natural enemies to control pest populations $[12,13,15]$. The amount of residue that remains on the soil surface and contributes to habitat complexity can vary with cover crop species, method of termination, and time allowed for growth prior to termination $[10,19]$. Therefore, management decisions that affect the resulting biomass of residue from cover crops may also affect the composition of the arthropod community in the succeeding cash crop.

Several studies have shown that cover crops and how they are managed can influence arthropod populations in succeeding crops. Koch et al. [20] compared the effects of early- and late-terminated winter rye (Secale cereale) on foliar arthropod counts in soybean (Glycine max). The presence of rye residue reduced potato leafhopper (Empoasca fabae) density compared to the no-cover crop treatment. Similarly, lower numbers of thrips were found in cotton (Gossypium hirsutum) when residues of rye or crimson clover (Trifolium incarnatum) remained on the soil surface [21]. However, Smith et al. [22] measured variable responses of different herbivorous insects to cover crop residue, with the lowest numbers of potato leafhopper and highest bean leaf beetle (Cerotoma trifurcata) and Japanese beetle (Popillia japonica) numbers in rye/no-till soybean compared to conventional tillage and treatments where rye was completely buried or absent. In addition to herbivores, their natural enemies may be influenced by cover crop residue. Lundgren and Fergen [23] found that autumn-planted slender wheatgrass (Elymus trachycaulus) increased subterranean predator diversity in the following maize crop compared to maize planted into fallow soil. Conversely, natural enemies may be uninfluenced by cover crop presence. For example, Jabbour et al. [24] found no effect of cover crop biomass on carabid numbers in soybean planted with a cereal cover crop on a two-year rotation with maize and soybean. Similarly, Blublaugh and Kaplan [25] found carabid numbers unchanged by the presence of rye and vetch (Vicia villosa) residue in soybeans.

Growers in USA can receive financial assistance to grow cover crops outside of the growing season through the United States Department of Agriculture's Environmental Quality Incentives Program (EQIP) for any farms where cover crops are identified as a Best Management Practice for promoting environmental conservation. Certain states, such as Maryland, New Jersey, and Delaware, have state-led programs funded through EQIP that specifically promote planting cover crops to promote soil health and water quality. Specific management practices, with respect to when and how cover crops are terminated, vary widely among individual farm operations. Variation in cover crop management techniques can affect the amount of cover crop residue that remains on the soil surface $[10,19,26]$, which impacts the resulting habitat complexity [18]. Variation in habitat complexity may alter the community composition of arthropods within soybean fields. In the Mid-Atlantic area, soybean producers typically terminate their cover crop with a post-emergent herbicide during early spring (early- to mid-April). However, other producers terminate their cover crop later in the season (mid- to late-May), which allows greater cover crop biomass accumulation. 
Though several studies have investigated how the method and timing of cover crop termination impact weed populations in grain crops, the impacts of these practices on arthropod populations are less well understood. The cover crop termination date is a crucial management tool for maximizing the benefits of these practices in agroecosystems [27]. As such, the overall goal of this study was to examine how different cover crop termination practices impact the foliar arthropod community within no-till soybean plantings. The cover crop termination practices chosen were designed to mimic some of the most common methods used by Mid-Atlantic soybean producers. Specific objectives were to compare the influence of termination method (chemical versus mechanical) and timing (early versus late) on arthropod populations. Barley (Hordeum vulgare) was chosen as the test cover crop partially because of its popularity among producers. A 2005 survey found that barley was the third most popular cereal grain cover crop in Maryland [28], behind wheat (Triticum spp.) and rye, and approximately 9300 ha were planted with a barley winter cover crop in Maryland in 2013 [29].

\section{Materials and Methods}

\subsection{Experimental Site, Layout, and Treatments}

Field experiments were conducted at the University of Maryland's Central Maryland Research and Education Center at the Upper Marlboro (38.859698, -76.778067) and Beltsville (39.012184, -76.826370) farm sites in 2013 and 2014. Field sites were previously farmed on a two-year maize (Zea mays) and soybean rotation with the exception of Beltsville in 2013, which was previously planted with grain sorghum (Sorghum bicolor) as opposed to maize. Field sites in Upper Marlboro were surrounded by production maize plantings, and in Beltsville, study sites were bordered by wooded areas on one side and production maize on the other. Treatments were replicated four times and arranged in a Latin square design. Individual plots measured $12 \mathrm{~m} \times 10 \mathrm{~m}$ and were separated by $6 \mathrm{~m}$ of natural vegetation that was regularly maintained with a rotary mower.

Each field experiment consisted of four treatments, including three cover crop termination methods and a fallow/bare-ground control. The three cover crop treatments included: (1) early-kill (EK), in which the cover crop was sprayed with post- and pre-emergent herbicides in mid-April; (2) late-kill (LK), in which the cover crop was sprayed with post- and pre-emergent herbicides in late May; and (3) flail-mowed (FM), in which the cover crop was sprayed with a pre-emergent herbicide and mowed in late May. An early-kill, flail-mowed treatment was not included in the experiment because mowing typically does not kill cover crops at early stages of development [30] and farmers do not use this method. The bare-ground treatment (BG) remained fallow after the previous crop was harvested, and received the same post- and pre-emergent herbicide applications as LK.

Barley "Nomini" was planted with a no-till drill into EK, LK, and FM plots at a rate of $135 \mathrm{~kg}$ $\mathrm{ha}^{-1}$ on 21 September 2012 and 24 September 2013 at both locations. Gramoxone SL ${ }^{\circledR}$ (paraquat, Syngenta Crop Protection LLC; Greensboro, NC, USA) was applied as a post-emergent herbicide using a tractor-mounted sprayer at $1.17 \mathrm{~L} \mathrm{ha}^{-1}$ at Beltsville and $2.34 \mathrm{~L} \mathrm{ha}^{-1}$ at the Upper Marlboro location. Authority ${ }^{\circledR}$ First (sulfentrazone, FMC Corporation, Agricultural Products Group; Philadelphia, PA, USA) was applied as a pre-emergent herbicide at all field locations at $329 \mathrm{~mL} \mathrm{ha}^{-1}$. Herbicides were applied using 196.4 $\mathrm{L} \mathrm{ha}^{-1}$ of carrier water at Upper Marlboro and $233.8 \mathrm{~L} \mathrm{ha}^{-1}$ at Beltsville. The EK treatment was sprayed with the post- and pre-emergent herbicide mixture on 15 April at Beltsville and 16 April at Upper Marlboro in 2013 and on 18 April at both sites in 2014. The LK treatment was sprayed with post- and pre-emergent herbicide mixture on the day soybeans were planted. The BG treatment received the same spray protocol as LK. The FM treatment was sprayed with the pre-emergent herbicide, and the cover crop was mowed on the day soybeans were planted.

The soybean was planted on 21 May at Beltsville and 20 May at Upper Marlboro in 2013 and 27 May 2014 at both sites. LibertyLink ${ }^{\circledR}$ maturity group four variety Stine 42LD02 (Bayer Crop Sciences; DeWitt, AR, USA) soybeans were planted with a no-till drill (model 1005, Great Plains Ag; Salinas, KS, USA) at 411,840 and 384,384 seeds $\mathrm{ha}^{-1}$ in 2013 and 2014, respectively. Soybeans were planted in 
wide rows ( $76 \mathrm{~cm}$ inter-row spacing) at Beltsville and narrow rows $(18 \mathrm{~cm}$ inter-row spacing) at Upper Marlboro. The initial protocol called for planting soybean at $76 \mathrm{~cm}$ row spacing at each site during both study years. However, the soybean was inadvertently planted at $18 \mathrm{~cm}$ spacing at Upper Marlboro during 2013. As a consequence, we opted to maintain this spacing at Upper Marlboro the following year. Still, it was not believed that this would impact the outcome, as earlier studies conducted in Maryland showed no impact of row spacing on the arthropod fauna in early- or late-planted soybean [31]. A late-season herbicide application of Ignite ${ }^{\circledR}$ (glufosinate, Bayer Crop Sciences; DeWitt, AR, USA) was applied at $511 \mathrm{~mL} \mathrm{ha}^{-1}$ on 11 July 2013 and 2 July 2014 to all plots at the Beltsville location as a "rescue" herbicide treatment primarily for large crabgrass (Digitaria sanguinalis). Soybeans were harvested at both sites using small plot combines, and yields were adjusted to $13 \%$ moisture. Data on soybean yields are presented in a separate manuscript. Specific spray, planting, and harvest dates are summarized in Table 1.

Table 1. Timing of field operations for 2013 and 2014 field experiments.

\begin{tabular}{|c|c|c|c|c|c|c|c|}
\hline Year & Location & Treatment $^{1}$ & Barley Planting ${ }^{2}$ & Herbicide Spray $^{3}$ & Soybean Planting & Late Herbicide & Harvest \\
\hline \multirow[t]{6}{*}{2013} & Beltsville & EK & 21 Sep & $15 \mathrm{Apr}$ & 21 May & $11 \mathrm{Jul}$ & 25 Oct \\
\hline & & LK & 21 Sep & 21 May & 21 May & $11 \mathrm{Jul}$ & 25 Oct \\
\hline & & FM & 21 Sep & 21 May & 21 May & $11 \mathrm{Jul}$ & 25 Oct \\
\hline & Upper Marlboro & EK & 21 Sep & $16 \mathrm{Apr}$ & 20 May & - & 8 Oct \\
\hline & & LK & 21 Sep & 20 May & 20 May & - & 8 Oct \\
\hline & & FM & 21 Sep & 20 May & 20 May & - & 8 Oct \\
\hline \multirow{6}{*}{2014} & & LK & 24 Sep & 27 May & 27 May & $2 \mathrm{Jul}$ & 24 Oct \\
\hline & & FM & 24 Sep & 27 May & 27 May & $2 \mathrm{Jul}$ & 24 Oct \\
\hline & & BG & - & 27 May & 27 May & $2 \mathrm{Jul}$ & 24 Oct \\
\hline & Upper Marlboro & EK & 24 Sep & $18 \mathrm{Apr}$ & 27 May & - & $25 \mathrm{Nov}$ \\
\hline & & LK & 24 Sep & 27 May & 27 May & - & $25 \mathrm{Nov}$ \\
\hline & & FM & 24 Sep & 27 May & 27 May & - & $25 \mathrm{Nov}$ \\
\hline
\end{tabular}

${ }^{1}$ EK = Early-kill, LK = Late-kill, FM = Flail-mow, BG = Bare-ground $;{ }^{2}$ Dates are for previous year; ${ }^{3}$ Each treatment received pre- and post-emergent herbicide sprays except FM, which received a pre-emergent herbicide spray only.

\subsection{Plant Biomass}

Cover crop and weed plant biomass were measured for each plot just prior to termination to determine barley and weed biomass production in cover crop and BG treatments. All vegetation was clipped at ground level within three (2013) or four (2014) replicate $0.25 \mathrm{~m}^{2}$ quadrats randomly placed in each plot. Samples were collected immediately before cover crop termination. Samples were then air-dried at $21^{\circ} \mathrm{C}$ for at least one week and weighed to determine plant dry biomass. Data on the persistence of cover crop residue were collected on a weekly basis, and are reported in a separate manuscript. 


\subsection{Arthropod Sampling}

Arthropod populations were measured by sweeping soybean foliage weekly with a $38.1 \mathrm{~cm}$ diameter canvas sweep net. A sweep sample consisted of two sets of five sweeps performed down two randomly selected rows at a sweeping width of $\sim 1 \mathrm{~m}$. Rows were haphazardly chosen for each sampling event, while excluding edge rows within each plot. Sampling was initiated at five or seven weeks after soybean planting (R1 growth stage) and was terminated at week 14 (R5 growth stage; Table 2). All sampling was conducted between the hours of 8:00 a.m. and 12:00 p.m. Arthropod sampling was carried out on eight dates in 2013, from 10 July to 30 August, and 10 dates in 2014, from 1 July to 3 September.

Sweep-captured arthropods were transferred into plastic zip-storage bags, sealed, and temporarily stored on ice in a portable cooler while in the field. They were then transported to the laboratory and stored in a freezer for later species identification and counting. Arthropod samples were sorted under magnification using a stereomicroscope and stored in vials containing $70 \%$ ethyl alcohol. Micro-parasitoid wasps were identified to the family level and placed separately in $85 \%$ ethyl alcohol for storage. Arthropod taxa were divided into predators and herbivores and grouped into six functional feeding guilds and spiders. Insect feeding guilds consisted of chewing predators, sucking predators, parasitoids, plant-sucking herbivores, pod feeders, and foliar feeders.

Table 2. Sample dates and soybean growth stages for both farm sites and years.

\begin{tabular}{lccccccccccc}
\hline & & \multicolumn{10}{c}{ Weeks after Planting } \\
\hline Year & Site & $\mathbf{5}$ & $\mathbf{6}$ & $\mathbf{7}$ & $\mathbf{8}$ & $\mathbf{9}$ & $\mathbf{1 0}$ & $\mathbf{1 1}$ & $\mathbf{1 2}$ & $\mathbf{1 3}$ & $\mathbf{1 4}$ \\
\hline 2013 & Beltsville & - & - & R1 & R2 & R3 & R3 & R3 & R3 & R4 & R5 \\
2013 & Upper Marlboro & - & - & R1 & R2 & R3 & R3 & R3 & R3 & R4 & R5 \\
2014 & Beltsville & R1 & R2 & R2 & R3 & R3 & R3 & R3 & R4 & R4 & R5 \\
2014 & Upper Marlboro & R1 & R1 & R2 & R3 & R3 & R3 & R3 & R4 & R4 & R5 \\
\hline
\end{tabular}

\subsection{Statistical Analyses}

Arthropod feeding guild composition was analyzed using constrained ordination methods with the package vegan [32]. Partial redundancy analysis (RDA) was used to determine the effect of cover crop treatment, soybean growth stage, and farm site on the overall composition of arthropod feeding guilds, while accounting for differences across years. Monte Carlo permutation tests were performed to test the significance of the multivariate model and each explanatory variable. Plant biomass of cover crop residue and winter weeds (fallow) and individual arthropod feeding guilds were analyzed with linear mixed models using the package lme4 [33]. Plant biomass was analyzed with treatment, farm site, and their interaction as fixed effects, and year as a random effect. Arthropod feeding guilds were analyzed with treatment, soybean growth stage, and farm site as fixed effects, and block and treatment as nested random effects to account for repeated measures over time. Mean abundances were calculated for soybean growth stages that spanned multiple sampling dates. Multiple means comparisons were performed for significant terms from the mixed models, using Tukey-adjusted $p$ values. All data for arthropod abundances were $\log _{10}(x+1)$ transformed to meet assumptions of normality and homogeneity of variances. Reported means are from untransformed data. All analyses were performed using the statistical program R [34]. 


\section{Results}

\subsection{Cover Crop Biomass}

There were significant effects of site, treatment, and the interaction of site and treatment on plant biomass at cover crop termination (site: Wald- $\chi^{2}=108.9, \mathrm{df}=1, p<0.001$; treatment: Wald- $\chi^{2}=223.5, \mathrm{df}=3$, $p<0.001$; site $\times$ treatment: Wald $\left.-\chi^{2}=42.7, \mathrm{df}=3, p<0.001\right)$. Within each farm site, flail-mowed (FM) and late-killed (LK) had higher plant biomass than early-killed (EK) or bare-ground (BG) treatments (Table 3). Total barley biomass in LK and FM treatments were more than two times greater at Beltsville than Upper Marlboro. No differences were detected in plant biomass between BG and EK treatments within each site, but there was greater weed biomass in the BG treatment at Beltsville than Upper Marlboro (Table 3).

Table 3. Cover crop and weed dry biomass just prior to their termination.

\begin{tabular}{|c|c|c|c|c|c|}
\hline \multirow{2}{*}{$\begin{array}{c}\text { Site } \\
\text { Beltsville }\end{array}$} & \multirow{2}{*}{$\begin{array}{c}\text { Treatment }^{1} \\
\text { EK }\end{array}$} & \multicolumn{3}{|c|}{ Mass \pm SEM $\left(\mathrm{kg} \mathrm{ha}^{-1}\right)$} & \multirow[b]{2}{*}{$\mathrm{cd}^{2}$} \\
\hline & & 160.1 & \pm & 60.5 & \\
\hline \multirow{7}{*}{ Upper Marlboro } & LK & 2211.9 & \pm & 83.2 & $\mathrm{a}$ \\
\hline & FM & 2123.4 & \pm & 112.9 & a \\
\hline & BG & 896.0 & \pm & 254.3 & bc \\
\hline & EK & 85.8 & \pm & 21.2 & $\mathrm{~d}$ \\
\hline & LK & 753.4 & \pm & 100.9 & $\mathrm{~b}$ \\
\hline & FM & 851.8 & \pm & 62.7 & $\mathrm{~b}$ \\
\hline & BG & 120.4 & \pm & 27.2 & $\mathrm{~d}$ \\
\hline
\end{tabular}

${ }^{1}$ EK = Early-kill, LK = Late-kill, FM = Flail-mow, BG = Bare-ground; ${ }^{2}$ Different letters indicate that means are significantly different $(p<0.05)$.

\subsection{Arthropod Counts}

In total, 54 families of arthropods were collected from sweep samples which included a total of 11,344 specimens. After averaging across multiple sample dates within similar soybean growth stages, a total of 6740 arthropods were analyzed. Approximately $98 \%$ of arthropods collected could be assigned to one of the seven feeding guilds (Table 4). Three feeding guilds, which included plant-sucking herbivores (25\%), foliage-feeding herbivores (24\%), and sucking predators (21\%), accounted for $70 \%$ of the entire arthropod community sampled.

The partial RDA explained $34.4 \%$ of the total variance in the community data, which was statistically significant $\left(\mathrm{F}_{8,70}=5.11, p=0.001\right)$. Tests of individual model terms showed farm site $\left(\mathrm{F}_{1,70}=9.23\right.$, $p=0.001)$ and soybean growth stage $\left(\mathrm{F}_{4,70}=4.74, p=0.001\right)$ to be significant explanatory variables. However, treatment did not explain a significant proportion of variance in feeding guild community data $\left(F_{3,70}=0.76, p=0.76\right)$. The biplot of the partial RDA shows centroids of soybean growth stages aligned along the first axis, with early growth stages (R1-3) in the positive direction and later stages (R4 and R5) in the negative direction (Figure 1). The first RDA axis explains $17.5 \%$ of the total community variance. Centroids for the two farm sites align with the second RDA axis, with Beltsville in the positive direction and Upper Marlboro in the negative direction (Figure 1). The second RDA axis explains $13.4 \%$ of the variance in the arthropod feeding guild data. All treatment centroids are clustered around the origin, as they do not explain a significant proportion of the variance in arthropod community composition. 


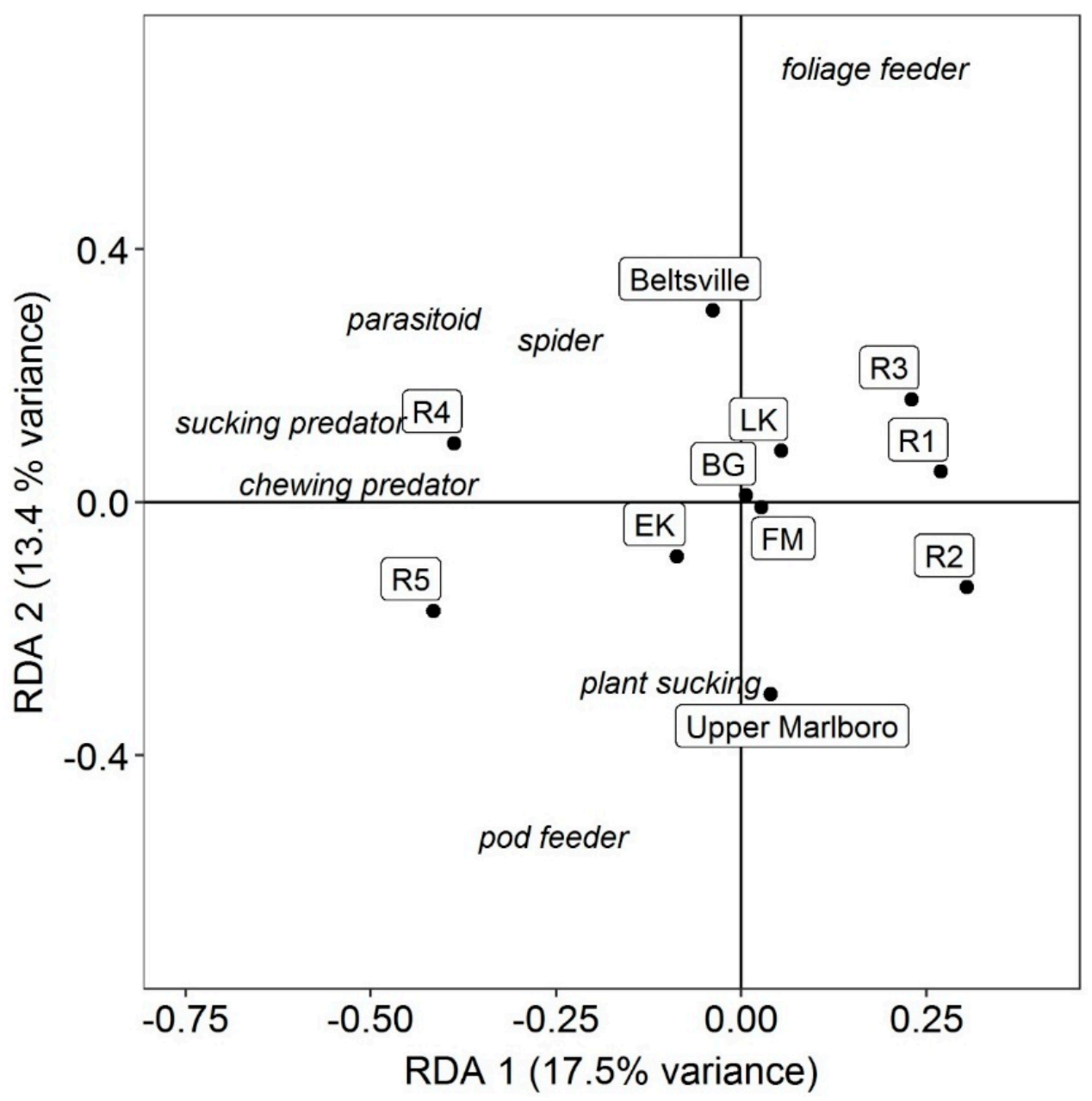

Figure 1. Biplot of partial redundancy analysis (RDA) of feeding guilds. Points represent centroids of explanatory variables labelled with text in boxes. Species scores for feeding guilds are represented by text in italics.

Linear mixed models found no significant treatment effect on the abundance of any arthropod feeding guild (Table 5). However, there was a significant effect of soybean development stage on each feeding guild, and farm site on all feeding guilds except chewing predators. There was also a significant stage $\times$ site interaction for parasitoids and all herbivore guilds. In general, parasitoid, chewing predator, and sucking predator guilds reached greatest abundance later in the season (R4 or R5 stage). In contrast, the numbers of foliage feeding and plant sucking herbivores peaked earlier at the R2 or R3 stage (Table 6). Sucking predators and spiders were found in greater numbers in Beltsville than Upper Marlboro across all soybean growth stages. 
Table 4. Arthropod feeding guilds and the abundance of arthropod families within those guilds. Abundances represent total raw counts from multiple sample dates within the same soybean growth stage.

\begin{tabular}{|c|c|c|c|c|c|}
\hline \multirow[b]{2}{*}{ Feeding Guild } & \multirow[b]{2}{*}{ Family } & \multicolumn{2}{|c|}{ Beltsville } & \multicolumn{2}{|c|}{ Upper Marlboro } \\
\hline & & $2013^{1}$ & 2014 & 2013 & 2014 \\
\hline \multirow[t]{10}{*}{ Spider } & Salticidae & 25 & 47 & 24 & 48 \\
\hline & Araneidae & 5 & 69 & 0 & 37 \\
\hline & Oxyopidae & 149 & 101 & 42 & 94 \\
\hline & Thomisidae & 18 & 16 & 35 & 11 \\
\hline & Lycosidae & 0 & 12 & 0 & 26 \\
\hline & Clubionidae & 0 & 3 & 0 & 0 \\
\hline & Ctenidae & 0 & 1 & 0 & 0 \\
\hline & Tetragnathidae & 0 & 8 & 0 & 9 \\
\hline & Linyphiidae & 0 & 4 & 0 & 2 \\
\hline & Pholcidae & 0 & 1 & 0 & 0 \\
\hline \multirow[t]{14}{*}{ Parasitoid } & Platygastridae & 159 & 11 & 57 & 0 \\
\hline & unspecified $^{2}$ & 0 & 407 & 0 & 104 \\
\hline & Sceleonidae & 10 & 23 & 1 & 15 \\
\hline & Chalcididae & 0 & 2 & 0 & 3 \\
\hline & Proctotrupidae & 0 & 1 & 0 & 2 \\
\hline & Braconidae & 0 & 76 & 0 & 29 \\
\hline & Eulophidae & 0 & 18 & 0 & 5 \\
\hline & Ichneumonidae & 0 & 8 & 0 & 3 \\
\hline & Tiphiidae & 0 & 178 & 0 & 25 \\
\hline & Aphelinidae & 0 & 1 & 0 & 1 \\
\hline & Encyrtidae & 0 & 1 & 0 & 0 \\
\hline & Mymaridae & 0 & 0 & 0 & 1 \\
\hline & Eurytomidae & 0 & 0 & 0 & 1 \\
\hline & Trichogrammatidae & 0 & 0 & 0 & 2 \\
\hline \multirow[t]{6}{*}{ Chewing predator } & Asilidae & 5 & 6 & 0 & 0 \\
\hline & Mantidae & 1 & 1 & 1 & 0 \\
\hline & Coccinellidae & 21 & 262 & 36 & 193 \\
\hline & Carabidae & 0 & 5 & 0 & 3 \\
\hline & Syrphidae & 0 & 101 & 0 & 4 \\
\hline & Cantharidae & 0 & 0 & 0 & 1 \\
\hline \multirow[t]{7}{*}{ Sucking predator } & Geocoridae & 543 & 346 & 223 & 326 \\
\hline & Pentatomidae & 3 & 8 & 1 & 1 \\
\hline & Chrysopidae & 5 & 1 & 3 & 13 \\
\hline & Anthocoridae & 48 & 166 & 225 & 161 \\
\hline & Nabidae & 100 & 340 & 37 & 93 \\
\hline & Hemerobiidae & 0 & 10 & 0 & 3 \\
\hline & Reduviidae & 0 & 0 & 0 & 4 \\
\hline \multirow[t]{7}{*}{ Foliage feeder } & Coccinellidae & 287 & 92 & 43 & 1 \\
\hline & Erebidae & 346 & 756 & 274 & 455 \\
\hline & Meloidae & 0 & 1 & 0 & 0 \\
\hline & Scarabaeidae & 428 & 284 & 90 & 96 \\
\hline & Chrysomelidae & 2 & 345 & 0 & 254 \\
\hline & Noctuidae & 0 & 1 & 0 & 0 \\
\hline & Hesperiidae & 0 & 3 & 0 & 0 \\
\hline
\end{tabular}


Table 4. Cont.

\begin{tabular}{cccccc}
\hline & & \multicolumn{2}{c}{ Beltsville } & \multicolumn{2}{c}{ Upper Marlboro } \\
\hline Feeding Guild & Family & $\mathbf{2 0 1 3}$ & $\mathbf{2 0 1 4}$ & $\mathbf{2 0 1 3}$ & $\mathbf{2 0 1 4}$ \\
\hline Plant sucking & Cicadellidae & 32 & 732 & 109 & 689 \\
& Membracidae & 22 & 0 & 40 & 18 \\
& unspecified & 404 & 0 & 896 & 0 \\
& Aphididae & 0 & 0 & 0 & 60 \\
Pod feeder & Pentatomidae & 33 & 164 & 69 & 115 \\
& Miridae & 112 & 102 & 108 & 229 \\
& unspecified & 0 & 2 & 67 & 30 \\
& Chrysomelidae & 0 & 0 & 0 & 2 \\
& Curculionidae & 2 & 5 & 0 & 30 \\
& Lampyridae & 4 & 21 & 17 & 5 \\
& Lygaeidae & 0 & 0 & 0 & 0 \\
& Elateridae & 18 & 5 & 0 & 12 \\
& Noctuidae & 0 & 0 & 0 & 1 \\
& Apidae & 0 & 0 & 1 & 0 \\
& Cynipidae & 0 & 0 & 18 & 3 \\
& Vespidae & 0 & 0 & 5 & 8 \\
& Chrysididae & 0 & 0 & 3 & 3 \\
& Pompilidae & 0 & 0 & 1 & 0 \\
& Scoliidae & 0 & 0 & 1 & 0 \\
& Thyreocoridae & 0 & 0 & 0 & 14 \\
& Berytidae & 0 & 0 & 0 & 41 \\
& Alydidae & 0 & 0 & 0 & 2 \\
\hline
\end{tabular}

${ }^{1} n=8$ for 2013 and $n=10$ for $2014 ;{ }^{2}$ taxa were not identified to the family level.

Table 5. Summary output of analysis of deviance performed on linear mixed models of feeding guilds.

\begin{tabular}{ccccc}
\hline Dependent Variable & Independent Variable & Wald- $\chi^{2}$ & $d f$ & $p$ \\
\hline spider & treatment & 6.06 & 3 & 0.109 \\
& stage & 24.37 & 4 & $<0.001$ \\
& site & 5.63 & 1 & 0.018 \\
& treatment $\times$ stage & 12.51 & 12 & 0.406 \\
& treatment $\times$ site & 4.61 & 3 & 0.203 \\
& stage $\times$ site & 4.81 & 4 & 0.308 \\
chewing predator & treatment $\times$ stage $\times$ site & 16.62 & 12 & 0.165 \\
& treatment & 4.46 & 3 & 0.216 \\
& stage & 134.41 & 4 & $<0.001$ \\
& site & 0.68 & 1 & 0.411 \\
& treatment $\times$ stage & 16.21 & 12 & 0.182 \\
& treatment $\times$ site & 3.99 & 3 & 0.263 \\
& stage $\times$ site & 4.98 & 4 & 0.289 \\
& treatment $\times$ stage $\times$ site & 10.21 & 12 & 0.597 \\
sucking predator & treatment & 3.62 & 3 & 0.306 \\
& stage & 113.88 & 4 & $<0.001$ \\
& site & 10.63 & 1 & 0.001 \\
& treatment $\times$ stage & 7.93 & 12 & 0.791 \\
\hline
\end{tabular}


Table 5. Cont.

\begin{tabular}{|c|c|c|c|c|}
\hline Dependent Variable & Independent Variable & Wald- $\chi^{2}$ & $d f$ & $p$ \\
\hline \multirow{8}{*}{ parasitoid } & treatment $\times$ site & 0.89 & 3 & 0.827 \\
\hline & stage $\times$ site & 3.54 & 4 & 0.472 \\
\hline & treatment $\times$ stage $\times$ site & 3.88 & 12 & 0.985 \\
\hline & treatment & 0.23 & 3 & 0.972 \\
\hline & stage & 57.56 & 4 & $<0.001$ \\
\hline & site & 60.10 & 1 & $<0.001$ \\
\hline & treatment $\times$ stage & 13.30 & 12 & 0.348 \\
\hline & treatment $\times$ site & 3.50 & 3 & 0.321 \\
\hline \multirow{8}{*}{ pod feeder } & stage $\times$ site & 12.90 & 4 & 0.012 \\
\hline & treatment $\times$ stage $\times$ site & 5.66 & 12 & 0.932 \\
\hline & treatment & 4.62 & 3 & 0.202 \\
\hline & stage & 25.11 & 4 & $<0.001$ \\
\hline & site & 31.81 & 1 & $<0.001$ \\
\hline & treatment $\times$ stage & 10.94 & 12 & 0.534 \\
\hline & treatment $\times$ site & 1.76 & 3 & 0.624 \\
\hline & stage $\times$ site & 18.26 & 4 & 0.001 \\
\hline \multirow{6}{*}{ plant sucking } & treatment $\times$ stage $\times$ site & 6.71 & 12 & 0.876 \\
\hline & treatment & 4.19 & 3 & 0.242 \\
\hline & stage & 29.22 & 4 & $<0.001$ \\
\hline & site & 6.97 & 1 & 0.008 \\
\hline & treatment $\times$ stage & 10.58 & 12 & 0.566 \\
\hline & treatment $\times$ site & 4.64 & 3 & 0.200 \\
\hline \multirow{9}{*}{ foliage feeder } & stage $\times$ site & 20.44 & 4 & $<0.001$ \\
\hline & treatment $\times$ stage $\times$ site & 4.19 & 12 & 0.980 \\
\hline & treatment & 2.21 & 3 & 0.531 \\
\hline & stage & 66.47 & 4 & $<0.001$ \\
\hline & site & 121.46 & 1 & $<0.001$ \\
\hline & treatment $\times$ stage & 17.73 & 12 & 0.124 \\
\hline & treatment $\times$ site & 5.03 & 3 & 0.170 \\
\hline & stage $\times$ site & 23.59 & 4 & $<0.001$ \\
\hline & treatment $\times$ stage $\times$ site & 13.52 & 12 & 0.332 \\
\hline
\end{tabular}


Table 6. Means ( \pm standard errors) of feeding guilds within farm site and soybean development stage.

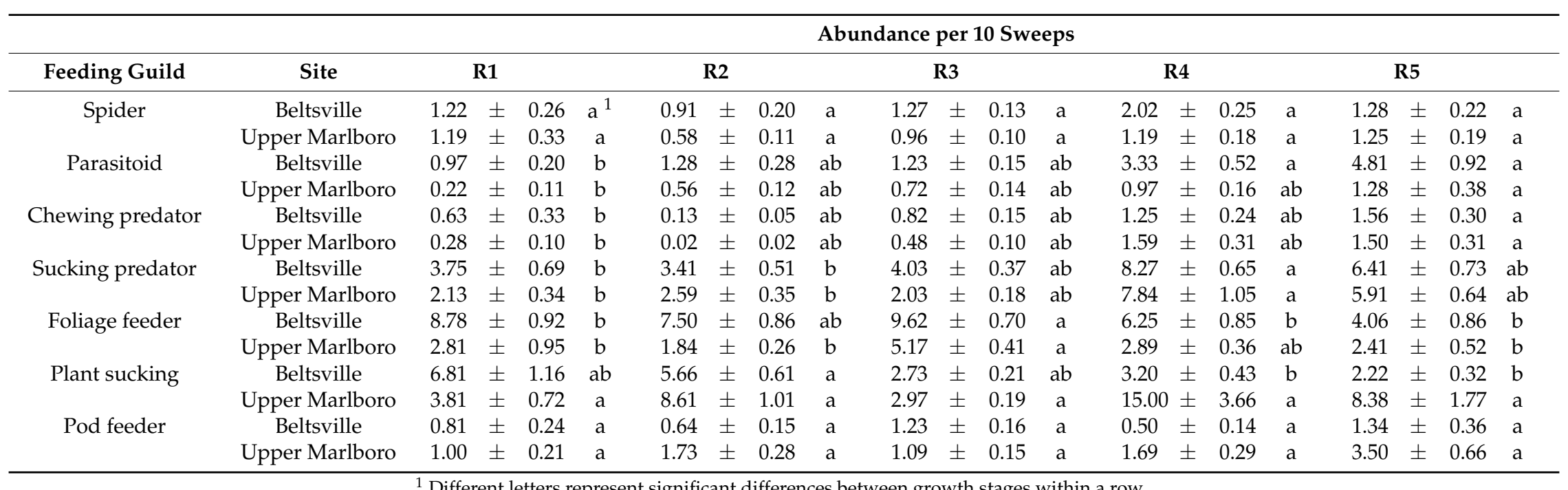

${ }^{1}$ Different letters represent significant differences between growth stages within a row. 


\section{Discussion}

The objective of this study was to quantify the impact of cover crop termination method and timing on the arthropod community within soybean foliage. Cover crop termination practices are known to impact invertebrates via resulting residues that remain in the cropping system [35]. Thus, it was hypothesized that different cover crop termination methods examined during this study would influence the arthropod community disparately. As projected, delaying the cover crop termination date resulted in significantly greater biomass of residue in late-kill (LK) and flail-mowed (FM) than in early-kill (EK) treatments. Averaged across years, delaying cover crop termination in FM and LK increased barley biomass relative to EK by $2007.5 \mathrm{~kg} \mathrm{ha}^{-1}$ at Beltsville and $716.8 \mathrm{~kg} \mathrm{ha}^{-1}$ at Upper Marlboro. Thus, it was hypothesized that this increased plant density and/or complexity would result in a concomitant increase in the number of predators such as spiders [36-38]. It was unclear if termination method (mechanical versus chemical) would cause differences in the community of foliar-dwelling arthropods. Additionally, the fallow (BG) treatment, which had some weeds prior to herbicide application, had limited amounts of plant residue remaining on the soil surface shortly afterwards. Thus, it was not anticipated that residue in BG would have a perceptible effect on arthropod numbers.

The total abundance of all feeding guilds within the soybean foliage responded similarly to treatments and their associated plant biomass distinctions. However, the arthropod community composition changed in response to soybean growth stage, which is a similar finding to that of Dunbar et al. [39]. These findings did not support our hypothesis that increased cover crop residue would benefit the arthropod community. Chemical (LK) and mechanical (FM) termination tactics also had similar effects on the arthropod community. This suggests that whether cover crops are killed early or late, or chemically or mechanically by mowing, the resulting arthropod community composition will be similar. The LK and EK treatments represent some of the most widely used practices for cover crop termination by Mid-Atlantic soybean producers, with the majority of producers choosing to terminate their cover crop "early" (early April) as opposed to "late" (at soybean planting from mid to late May). The results of our study suggest that the two cover crop termination practices are likely to result in similar foliar arthropod communities during the reproductive stages of the soybean plant development.

Relatively few other studies have found strong effects of residue from fall-planted cover crops on the foliar arthropod community in the succeeding agronomic crop. Koch et al. [20] found that fall-planted rye reduced the abundances of some herbivorous insect species on soybean plants, but did not significantly affect predacious species. Conversely, Hooks et al. [40] found greater populations of spiders on soybean foliage in treatments with Italian ryegrass (Lolium multiflorum) cover crop residue compared to treatments without cover crop residue, but did not measure any differences in herbivorous species. Other studies have found no consistent effect of cover crop residue on arthropod herbivores or predators within soybean $[39,41]$ or maize $[39,42,43]$ foliage. However, several studies have found greater numbers of ground-dwelling arthropods in field crops with greater cover crop residue [39,44-46]. As such, it is possible that epigeal predators may have responded to cover crop residue differently than those inhabiting soybean foliage.

Cover crop treatments from this experiment may have failed to have an effect on the arthropod community for several reasons. The amount of residue produced by the barley cover crop may not have been sufficient to influence the arthropod community within the soybean canopy. Studies investigating the effect of cover crop residue on the resulting arthropod community often do not report the biomass of cover crop residue, which makes it difficult to determine whether there is a minimum amount of residue required to significantly alter the arthropod community. Further, pest pressures at study sites may have been too low to detect any perceptible treatment effect or an associated numeric response from predators. 


\section{Conclusions}

This study evaluated influences of timing and method of cover crop termination practices on arthropod communities within subsequent crops. During this investigation, the focus was on arthropods within the soybean foliage, as the belief is that these arthropods have the greatest impact on soybean productivity. Overall, our results indicate that cover crop termination methods that result in greater cover crop biomass will have no effect on the arthropod community within the soybean foliage. If delaying cover crop termination results in greater weed suppression without impacting soybean productivity, this practice should nevertheless make soybean systems more resilient to pest pressure and acceptable by soybean producers [10]. Cover crop termination date is a crucial management variable for maximizing overall benefits of cover crops to agricultural systems, and several factors within an agroecosystem may be impacted. However, most studies conducted to examine the influence of cover crop residue on cropping systems have studied their impact on specific agroecosystem services. As such, multidisciplinary studies are needed to provide a fuller assessment of the impact of cover crop termination date and method on agroecosystem services.

Author Contributions: G.C. and C.R.R.H. conceived of and designed the study, A.R.-L. performed the experiments, A.W.L. analyzed the data and all authors contributed to writing the paper.

Acknowledgments: We thank crews at the Upper Marlboro and Beltsville Research and Education Centers for logistics in establishing field trials. This work was supported by Hatch Project No. MD-ENTO-9107/project accession no. 227029 from the USDA National Institute of Food and Agriculture and grant monies from the Maryland Soybean Board. We also thank three anonymous reviewers for helpful feedback and suggestions for improving this manuscript.

Conflicts of Interest: The authors declare no conflict of interest. The funding sponsors had no role in the design of the study; in the collection, analyses, or interpretation of data; in the writing of the manuscript, or in the decision to publish the results.

\section{References}

1. Unger, P.W.; Vigil, M.F. Cover crop effects on soil water relationships. J. Soil Water Conserv. 1998, 53, $200-207$.

2. Price, A.J.; Arriaga, F.J.; Raper, R.L.; Balkcom, K.S.; Komecki, T.S.; Reeves, D.W. Comparison of mechanical and chemical winter cereal cover crop termination systems and cotton yield in conservation agriculture. J. Cotton Sci. 2009, 13, 238-245.

3. Liebman, M.; Dyck, E. Crop-rotation and intercropping strategies for weed management. Ecol. Appl. 1993, 3, 92-122. [CrossRef] [PubMed]

4. Hooks, C.R.R.; Hinds, J.; Zobel, E.; Patton, T. Impact of crimson clover dying mulch on two eggplant insect herbivores. J. Appl. Entomol. 2013, 137, 170-180. [CrossRef]

5. Brainard, D.C.; Bellinder, R.R. Weed suppression in a broccoli-winter rye intercropping system. Weed Sci. 2004, 52, 281-290. [CrossRef]

6. Morton, T.A.; Bergtold, J.S.; Price, A.J. The economics of cover crop biomass for corn and cotton. In Proceedings of the Southern Conservation Systems Conference, Amarillo, TX, USA, 26-28 June 2006; pp. 69-76.

7. Teasdale, J.R. Interaction of light, soil moisture, and temperature with weed suppression by hairy vetch residue. Weed Sci. 1993, 41, 46-51. [CrossRef]

8. Creamer, N.G.; Bennett, M.A.; Stinner, B.R.; Cardina, J.; Regnier, E.E. Mechanisms of weed suppression in cover crop-based production systems. HortScience 1996, 31, 410-413.

9. Putnam, A.R.; Defrank, J.; Barnes, J.P. Exploitation of allelopathy for weed control in annual and perennial cropping systems. J. Chem. Ecol. 1983, 9, 1001-1010. [CrossRef] [PubMed]

10. Mirsky, S.B.; Ryan, M.R.; Teasdale, J.R.; Curran, W.S.; Reberg-Horton, C.S.; Spargo, J.T.; Wells, M.S.; Keene, C.L.; Moyer, J.W. Overcoming weed management challenges in cover crop-based organic rotational no-till soybean production in the eastern United States. Weed Technol. 2013, 27, 193-203. [CrossRef]

11. Mohler, C.L.; Teasdale, J.R. Response of weed emergence to rate of Vicia villosa Roth and Secale cereale L. residue. Weed Res. 1993, 33, 487-499. [CrossRef] 
12. Lawton, J.H.; Strong, D.R., Jr. Community patterns and competition in folivorous insects. Am. Nat. 1981, 118, 317-338. [CrossRef]

13. Altieri, M.A. The ecological role of biodiversity in agroecosystems. Agric. Ecosyst. Environ. 1999, 74, $19-31$. [CrossRef]

14. Landis, D.A.; Wratten, S.D.; Gurr, G.M. Habitat management to conserve natural enemies of arthropod pests in agriculture. Annu. Rev. 2000, 45, 175-201. [CrossRef] [PubMed]

15. Obermaier, E.; Heisswolf, A.; Poethke, J.; Randlkofer, B.; Meiners, T. Plant architecture and vegetation structure: Two ways for insect herbivores to escape parasitism. Eur. J. Entomol. 2008, 105, 233-240. [CrossRef]

16. Mulvaney, M.J.; Price, A.J.; Wood, C.W. Cover crop residue and organic mulches provide weed control during limited-input no-till collard production. J. Sustain. Agric. 2011, 35, 312-328. [CrossRef]

17. Bryant, A.; Brainard, D.C.; Haramoto, E.R.; Szendrei, Z. Cover crop mulch and weed management influence arthropod communities in strip-tilled cabbage. Environ. Entomol. 2013, 42, 293-306. [CrossRef] [PubMed]

18. Bryant, A.; Coudron, T.; Brainard, D.; Szendrei, Z. Cover crop mulches influence biological control of the imported cabbageworm (Pieris rapae L., Lepidoptera: Pieridae) in cabbage. Biol. Control 2014, 73, 75-83. [CrossRef]

19. Wortman, S.E.; Francis, C.A.; Bernards, M.L.; Drijber, R.A.; Lindquist, J.L. Optimizing cover crop benefits with diverse mixtures and an alternative termination method. Agron. J. 2012, 104, 1425-1435. [CrossRef]

20. Koch, R.L.; Porter, P.M.; Harbur, M.M.; Abrahamson, M.D.; Wyckhuys, K.A.G.; Ragsdale, D.W.; Buckman, K.; Sezen, Z.; Heimpel, G.E. Response of soybean insects to an autumn-seeded rye cover crop. Environ. Entomol. 2012, 41, 750-760. [CrossRef]

21. Olson, D.M.; Davis, R.F.; Brown, S.L.; Roberts, P.; Phatak, S.C. Cover crop, rye residue and in-furrow treatment effects on thrips. J. Appl. Entomol. 2006, 130, 302-308. [CrossRef]

22. Smith, A.W.; Hammond, R.B.; Strinner, B.R. Influence of rye-cover crop management on soybean foliage arthropods. Environ. Entomol. 1988, 17, 109-114. [CrossRef]

23. Lundgren, J.G.; Fergen, J.K. Enhancing predation of a subterranean insect pest: A conservation benefit of winter vegetation in agroecosystems. Appl. Soil Ecol. 2011, 51, 9-16. [CrossRef]

24. Jabbour, R.; Pisani-Gareau, T.; Smith, R.G.; Mullen, C.; Barbercheck, M.E. Cover crop and tillage intensities alter ground-dwelling arthropod communities during the transition to organic production. Renew. Agric. Food Syst. 2015, 31, 361-374. [CrossRef]

25. Blubaugh, C.K.; Kaplan, I. Tillage compromises weed seed predator activity across developmental stages. Biol. Control 2015, 81, 76-82. [CrossRef]

26. Jackson, D.M.; Harrison, H.F. Effects of a killed-cover crop mulching system on sweetpotato production, soil pests, and insect predators in South Carolina. J. Econ. Entomol. 2008, 101, 1871-1880. [CrossRef] [PubMed]

27. Alonso-Ayuso, M.; Gabriel, J.L.; Quemada, M. The kill date as a management tool for cover cropping success. PLoS ONE 2014, 9, e109587. [CrossRef] [PubMed]

28. Hance, E.; Harks, D.P. Agriculture in Maryland Summary for 2013; Maryland Department of Agriculture: Annapolis, MD, USA, 2014.

29. Schaefer Center for Public Policy. Maryland Farmers' Winter Cover Crop Participation: Report on a Mail Survey and Four Focus Groups of Maryland Farmers; Maryland Department of Agriculture: Annapolis, MD, USA, 2005.

30. Creamer, N.G.; Dabney, S.M. Killing cover crops mechanically: Review of recent literature and assessment of new research results. Am. J. Altern. Agric. 2002, 17, 32-40.

31. Buchanan, A.L.; Zobel, E.; Hinds, J.; Rosario-Lebron, A.; Hooks, C.R.R. Can row spacing influence arthropod communities in soybean? Implications for early and late planting. Environ. Entomol. 2015, 44, 557-561. [CrossRef] [PubMed]

32. Oksanen, J.; Friendly, F.G.B.M.; Kindt, R.; Legendre, P.; McGlinn, D.; Minchin, P.R.; O'Hara, R.B.; Simpson, G.L.; Solymos, P.; Stevens, M.H.H.; et al. Vegan 2.4-6: Community ecology package. Available online: https:/ / crantastic.org/packages/vegan/versions/67602 (accessed on 20 April 2018).

33. Bates, D.; Mächler, M.; Bolker, B.; Walker, S. Fitting linear mixed-effects models using lme4. J. Stat. Softw. 2015, 67, 1-48. [CrossRef]

34. R Core Team. R: A Language Environment for Statistical Computing; R Found. Stat. Comput.: Vienna, Austria, 2016.

35. Tremelling, M.J.; McSorley, R.; Gallaher, R.N. Effects of winter cover crops on the soil surface invertebrate community. Soil Crop Sci. Soc. Fla. Proc. 2002, 62, 77-82. 
36. Young, O.P.; Edwards, G.B. Spiders in United States field crops and their potential effect on crop pests. J. Arachnol. 1990, 18, 1-27. [CrossRef]

37. Chen, L.L.; You, M.S.; Chen, S.B. Effects of cover crops on spider communities in tea plantations. Biol. Control 2011, 59, 326-335. [CrossRef]

38. Sunderland, K.; Samu, F. Effects of agricultural diversification on the abundance, distribution, and pest control potential of spiders. Entomol. Exp. Appl. 2000, 95, 1-13.

39. Dunbar, M.W.; Gassmann, A.J.; O'Neal, M.E. Limited impact of a fall-seeded, spring-terminated rye cover crop on beneficial arthropods. Environ. Entomol. 2017, 46, 284-290. [CrossRef] [PubMed]

40. Hooks, C.R.R.; Wang, K.-H.; Meyer, S.L.; Lekveishvili, M.; Hinds, J.; Zobel, E.; Rosario-Lebron, A.; Lee-Bullock, M. Impact of no-till cover cropping of Italian ryegrass on above and below ground faunal communities inhabiting a soybean field with emphasis on soybean cyst nematodes. J. Nematol. 2011, 43, 172-181. [PubMed]

41. Leslie, A.W.; Wang, K.-H.; Meyer, S.L.F.; Marahatta, S.; Hooks, C.R.R. Influence of cover crops on arthropods, free-living nematodes, and yield in a succeeding no-till soybean crop. Appl. Soil Ecol. 2017, 117-118, 21-31. [CrossRef]

42. Fox, A.F.; Kim, T.N.; Bahlai, C.A.; Woltz, J.M.; Gratton, C.; Landis, D.A. Cover crops have neutral effects on predator communities and biological control services in annual cellulosic bioenergy cropping systems. Agric. Ecosyst. Environ. 2016, 232, 101-109. [CrossRef]

43. Davis, H.N.; Currie, R.S.; Klocke, N.L.; Buschman, L.L. Winter annual cover crop has only minor effects on major corn arthropod pests. J. Econ. Entomol. 2010, 103, 348-355. [CrossRef] [PubMed]

44. Laub, C.A.; Luna, J.M. Winter cover crop suppression practices and natural enemies of armyworm (Lepidoptera: Noctuidae) in no-till corn. Environ. Entomol. 1992, 21, 41-49. [CrossRef]

45. Gill, H.K.; McSorley, R.; Branham, M. Effect of organic mulches on soil surface insects and other arthropods. Fla. Entomol. 2011, 94, 226-232. [CrossRef]

46. House, G.J.; Alzugaray, M.D.R. Influence of cover cropping and no-tillage practices on community composition of soil arthropods in a North Carolina agroecosystem. Environ. Entomol. 1989, 18, 302-307. [CrossRef]

(C) 2018 by the authors. Licensee MDPI, Basel, Switzerland. This article is an open access article distributed under the terms and conditions of the Creative Commons Attribution (CC BY) license (http://creativecommons.org/licenses/by/4.0/). 